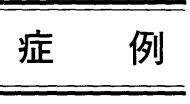

\title{
Peripheral adenoid cystic carcinoma of the lung
}

a case report-

Pathology Section, Kanazawa University Hospital, Department of Internal Medicine ${ }^{1)}$, Department of Surgery ${ }^{2)}$, Department of Radiology ${ }^{3)}$, School of Medicine, Department of Medical Technology ${ }^{4}$, School of Allied Medical Professions, Kanazawa University and Department of Pathology ${ }^{5)}$, Toyama Medical and Pharmaceutical University, Faculty of Medicine

\begin{abstract}
Akitaka Nonomura, Yuji Mizukami, Shinobu Nakamura ${ }^{1)}$, Yoh Watanabe ${ }^{2)}$ Tsutomu Takashima ${ }^{3)}$, Kazuo Tanimoto ${ }^{4)}$, Masanobu Kitagawa ${ }^{5)}$
\end{abstract}

Adenoid cystic carcinoma of the lung occurs commonly in the trachea and main bronchi and rarely occurs as a peripheral lung mass. A case of peripheral adenoid cystic carcinoma of the lung is reported. The patient was a 67-year-old Japanese female who had the complaint of cough for one and half months. On admission to the hospital, she was found to have a left abnormal lung mass. She was transferred to the Surgical Department of Kanazawa University Hospital for further examination and surgery. A tumor was located in the left superior lingula segment ( $\mathrm{S}-4 \mathrm{~b}$ ), and was resected. The cut surface of the tumor was yellow-white and measured $2.3 \times 3.0 \times 2.6 \mathrm{~cm}$ with a well-defined margin. There was no relationship between the tumor and the trachea or main bronchus. Histologic and electron microscopic examination revealed the tumor to be an adenoid cystic carcinoma. Histologically, there was no involvement of the main bronchi in the tumor, but bronchi without cartilage were found at the periphery of the tumor, which indicated that the tumor might arise from the fifth or sixth order bronchus.

\footnotetext{
Akitaka NONOMURA, M.D., Yuji MIZUKAMI, M.D., Shinobu NAKAMURA ${ }^{1)}$, M.D., M.I.A.C., Yoh WATANABE ${ }^{2)}$, M.D., Tsutomu TAKASHIMA ${ }^{3)}$, M.D., Kazuo TANIMOTO ${ }^{4}$, M.D., M.I.A.C., F.I.A.C., Masanobu KITAGAWA ${ }^{5}$, M.D.

Pathology Section, Kanazawa University Hospital, ${ }^{11} \mathrm{De}$ partment of Internal Medicine, ${ }^{2)}$ Department of Surgery, ${ }^{3)}$ Department of Radiology, School of Medicine, ${ }^{4}$ Department of Medical Technology, School of Allied Medical Professions, Kanazawa University, ${ }^{5}$ Department of Pathology, Toyama Medical and Pharmaceutical University, Faculty of Medicine, Toyama

Address for reprints request: Akitaka Nonomura, M.D., Pathology Section, Kanazawa University Hospital, School of Medicine, Kanazawa University, 13-1 Takara-machi, Kanazawa, Ishikawa, Japan

平成 4 年 5 月 30 日受付

平成 4 年 9 月 4 日受理
}

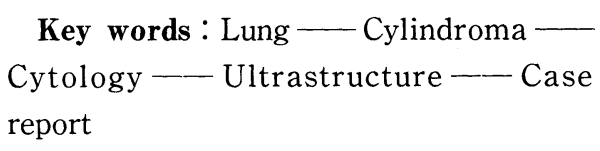

\section{Introduction}

Adenoid cystic carcinoma is an uncommon and specific variant of adenocarcinoma that occurs most frequently in the major and minor salivary glands ${ }^{7}$. This tumor also occurs in the breast, uterine cervix ${ }^{12)}$, larynx ${ }^{9)}$, Bartholin's gland ${ }^{1)}$ skin $^{5)}$ 
and trachea and bronchus ${ }^{4}$. However, the occurrence of a primary adenoid cystic carcinoma as a large peripheral lung mass is extremely rare, and few cases have been reported to date $e^{2,3,10)}$. We report a case of peripheral adenoid cystic carcinoma of the lung along with electron microscopic and cytological findings.

\section{Case report}

A 67-year-old woman with a complaint of cough for one and half months, was admitted to a hospital where she was found to have an abnormal shadow in the left lung. She was transferred to the Department of Surgery, Kanazawa University Hospital, for further examination. She had no history of smoking. Physical examination revealed a wellnourished woman without superficial lymphadenopathy. Laboratory data were within the normal range. Preoperative chest films revealed a $3.5 \mathrm{~cm}$ mass with a rather clear demarcation in the left upper lobe. The sputum culture was normal. Tumor aspiration cytology was performed but no tumor cells were found. Exploratory thoracotomy was performed on February 10, 1988. The pathologic examination during surgery by frozen section revealed an adenoid cystic carcinoma, and an upper lobectomy was performed.

\section{Pathologic findings}

A resected lung specimen was fixed in 10\% buffered formalin. A routine histologic examination was performed after paraffin embedding and staining with hematoxylin-eosin ( $\mathrm{H} \& \mathrm{E}$ ), Alcian blue, periodic acid Schiff (PAS), and elastica van Gieson stain. Tumor imprint specimens were fixed in $95 \%$ ethanol for Papanicolaou stain, or air-dried and fixed in $95 \%$ methanol for May-Grüenwald-Giemsa stain.

For electron microscopy, fresh samples of the lung tumor were minced into small cubes and fixed in $2.5 \%$ glutaraldehyde in phosphate-buffered saline (PBS), postfixed in $1 \%$ osmium tetroxide in

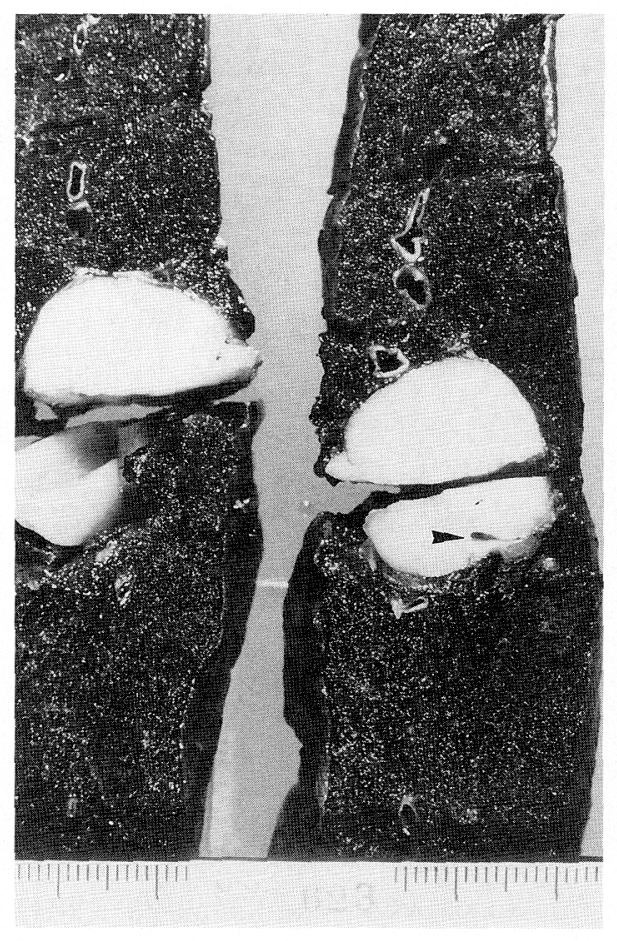

Fig. 1 Macroscopic appearance of the lung tumor located in the peripheral lung parenchyma, showing a yellow-white cut surface with well-defined margin. The arrowhead indicates a small pul. monary artery located in the periph. ery of the tumor

PBS, and embedded in Epon 812. Ultrathin sections were stained with uranyl acetate-lead citrate, and examined under a transmission electron microscope.

Macroscopically, the tumor was located in the left superior lingula segment $(S-4 \mathrm{~b})$. The cut surface of the tumor was homogeneously yellow-white with a well-circumscribed border, and measured $2.3 \times$ $3.0 \times 2.6 \mathrm{~cm}$ (Fig. 1). The tumor was located in the periphery of the lung parenchyma. No particular relationship was observed between the tumor and the main bronchus. The small pulmonary artery and bronchus were seen at the periphery of the tumor.

Microscopically, the main bronchus was not entrapped in the tumor, but two small bronchi without cartilage were found at the periphery of the 


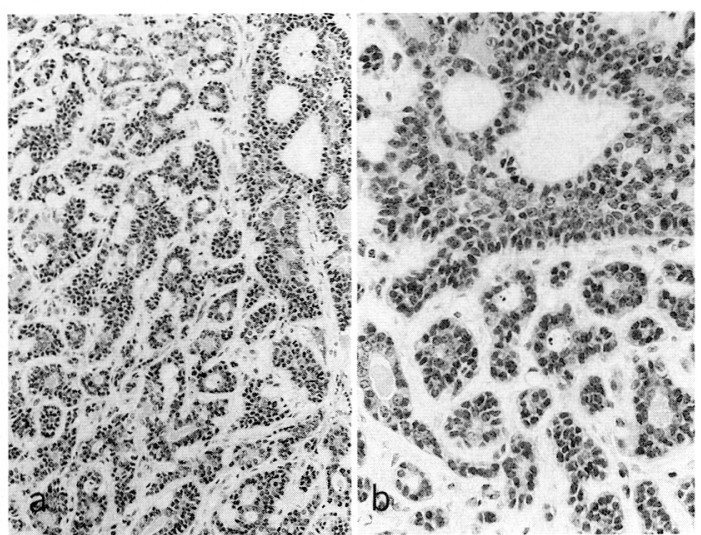

Fig. 2 Microscopic appearance of the tumor, showing small, round cells arranged in characteristic strand, tubular, or cribriform pattern. $\mathrm{H}-\mathrm{E}$ stain. Original magnification $(\mathrm{a} ; \times 200, \mathrm{~b} ; \times$ 400)

tumor. The tumor cells were rather small and uniform with round or ovoid nuclei and formed strands or clumps with varying numbers of cystic or alveolar spaces forming an interlacing cylinder or cribriform pattern. Tubular and solid patterns also were found in varying degrees in the tumor (Fig. 2). The center of the cylinder or tubule was filled with mucin positively stained with PAS and Alcian blue. The stroma was also positively stained with Alcian blue to varying degrees. There was no metastases in the regional lymph nodes.

Fig. 3. shows the cytologic features of the tumor imprint specimen. The tumor cells in ball-like clusters were small and rounded with little variation in size, and showed a low degree of atypia. The nuclei of the tumor cells had fine granular chromatin and small but prominent nucleoli. A characteristic feature was the presence of a central core of homogeneous mucinous substance corresponding to the material filling the cystic spaces. The size of the central core was various. The small one gave an appearance of a rosette-like structure with central acellular area.

Examination by electron microscopy revealed a tumor composed of islands of polygonal cells surrounded by basal lamina, and containing scattered spaces through the islands (Fig. 4). Some of the

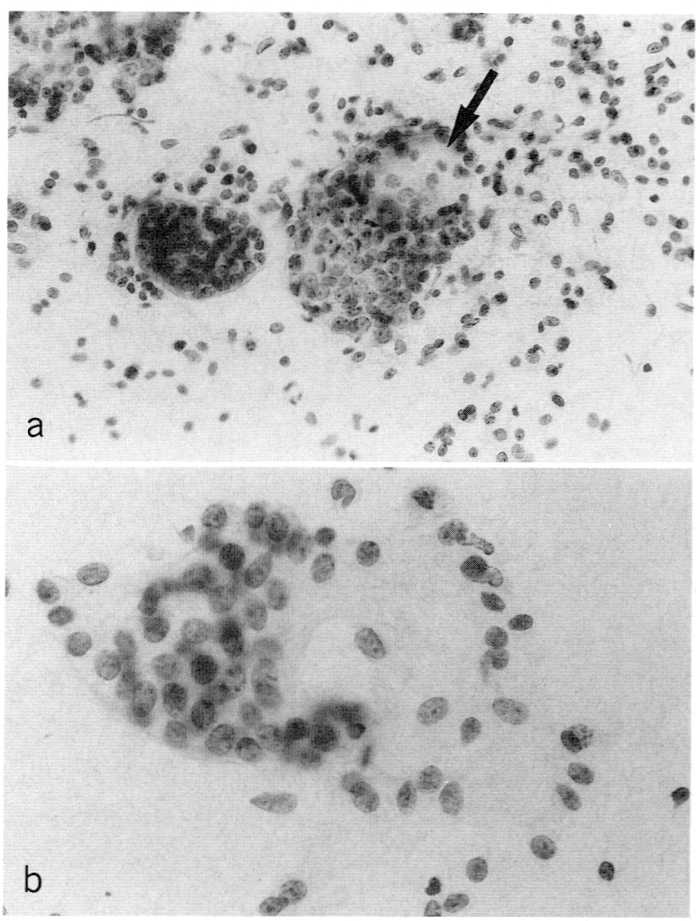

Fig. 3 Cytologic features of the tumor imprint specimen (a, b), showing ball-like clusters (a) with a core of homogeneous mucinous substance(a, arrow). Higher magnification shows that tumor cells are small and round with little variation in size, and show a low degree of atypia(b). Original magnification $(\mathrm{a} ; \times 400$, b : $\times 800)$

spaces were filled with basal laminar material and the others were composed of epithelial-type lining with junctional complexes and microvilli at their luminal surfaces (Fig. 5), each corresponding to pseudolumens and true lumens, respectively. In addition, the tumor cells tended to be separated from one another and to have lateral cytoplasmic processes projecting into the intercellular spaces (Fig. 4).

\section{Clinical course}

After establishing the tumor histology, an extensive survey for the presence of another tumor was performed to exclude the possibility of this tumor being a metastasis, but no tumor was found outside the lung. Furthermore, no recurrence or other 


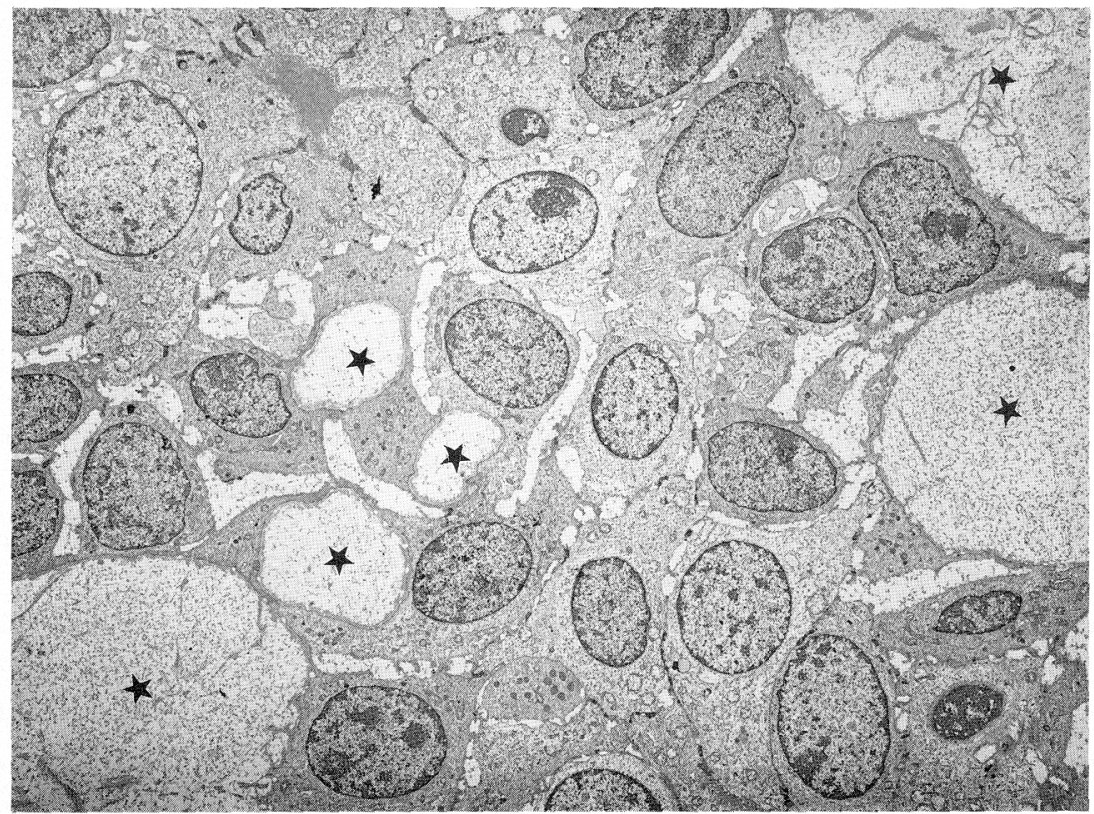

Fig. 4 Electron microscopic features of the tumor, showing islands of polygonal tumor cells with cystic spaces containing basal laminar materials (asterisks) and irregular intercellular spaces with lateral cytoplasmic projections $(\times 3,400)$

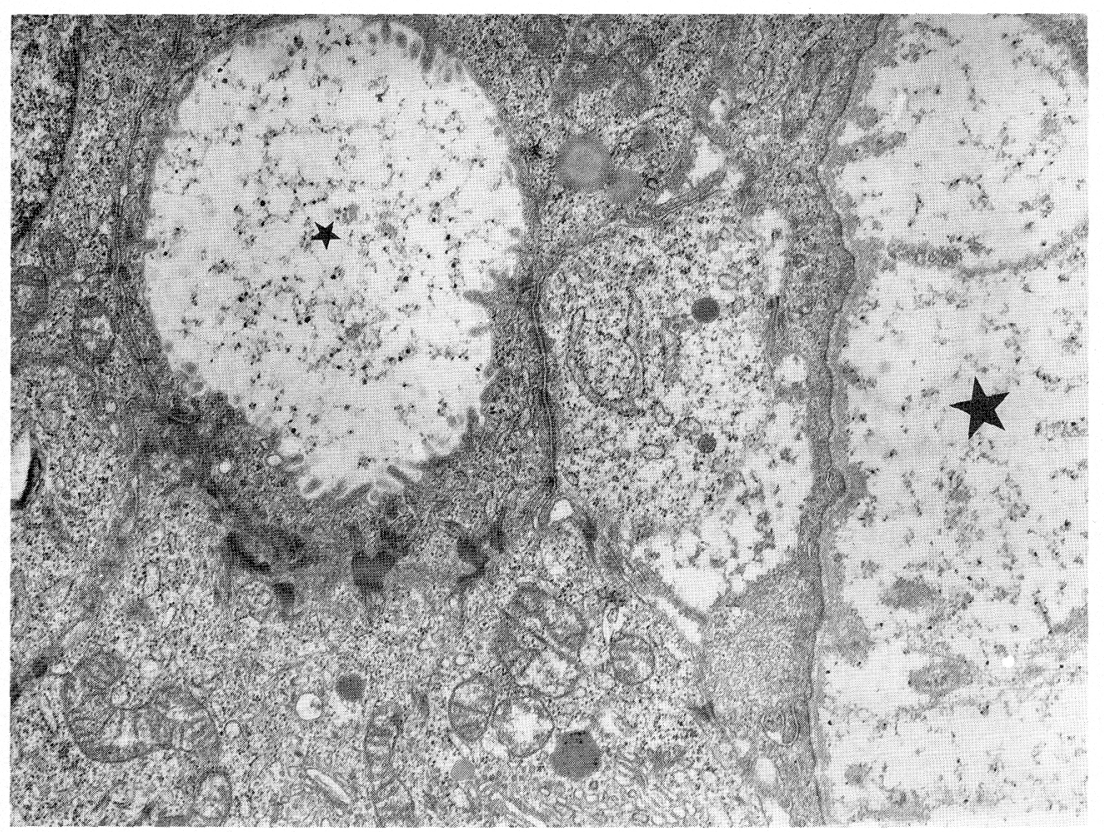

Fig. 5 Tumor cells on the left are separated by cystic space filled with basal laminar material (large asterisk) and the ones on the right form the true lumen (small asterisk) with microvilli and junctional complexes $(\times 17,000)$ 
primary tumors have been found during the followup period for 4 years and 6 months after surgery, and the patient remains free of recurrence.

\section{Discussion}

Primary lung tumors are generally classified according to the type of lung tissue they originate from; bronchial epithelial, mucous gland, and mesenchymal origin ${ }^{11}$. Adenoid cystic carcinoma is a histopathologically distinct tumor which originates from the mucous glands. In a large series of primary lung tumors, adenoid cystic carcinoma constituted only 3 out of 1,500 cases $(0.2 \%)^{14)}$. Adenoid cystic carcinoma of the lung occures commonly in the trachea and main bronchus ${ }^{11,14)}$. Occurrence of adenoid cystic carcinoma in the peripheral lung tissue is extremely rare and only a few cases have been reported so $\mathrm{far}^{2,3,10)}$. Gallagher et al. reported a case of a 48-year-old female with peripheral adenoid cystic carcinoma of the lung who had had multiple nodules 11 years after resection of the original tumor ${ }^{3}$. Dalton et al. reported a case of peripheral adenoid cystic carcinoma, presenting as a large peripheral lung mass, measured about $10 \times 9 \times 6 \mathrm{~cm}$ in a 63 -year-old female $^{2)}$. Okura et al. reported a 70-year-old Japanese woman who had an adenoid cystic carcinoma measuring $1.5 \times 1.5 \mathrm{~cm}$ in the left upper lobe of the lung $(\mathrm{S} 1+2)^{10)}$. Bronchial glands have been reported present in the bronchi down to a diameter of about $1.0 \mathrm{~mm}$ and reach their greatest development in the second to the fifth order bronchi ${ }^{13)}$. Mitani studied the occurrence of human bronchial glands in bronchi of different orders and reported that all studied cases had both bronchial glands and cartilage from the first to fourth order, whereas bronchial glands were found in $79 \%$ of the fifth order bronchi but only in $11 \%$ of the sixth order. Cartilage was seen in $89 \%$ of the fifth order bronchi and $44 \%$ of the sixth order bronchi. No bronchi more than the seventh order had bronchial glands or cartilage $^{8}$. Therefore, adenoid cystic carcinoma may occur in bronchi of up to the sixth order. In the present case, the relationship of the tumor to the trachea and main bronchus was not demonstrated but bronchi without cartilage were found at the periphery of the tumor. Therefore, the tumor might arise from the bronchus of fifth or sixth order bronchus.

Adenoid cystic carcinoma is believed to grow slowly and to have a high rate of invasiveness and local recurrence, and a definite but low potentiality for distant metastasis. The tumor is composed of two cell types, duct-lining cells and cells of myoepithelial type, forming a characteristic cribriform pattern ${ }^{6,15)}$. This tumor is histologically and ultrastructurally identical to the salivary gland, breast, or uterine cervix tumor of same name $e^{6,7,14}$.

Electron microscopically, the tumor was characterized by islands with polygonal cells with numerous sieve-like spaces scattered through the islands. Some cystic spaces were composed of epithelial-type lining cells with microvilli and junctional complexes, and the others were filled with basal laminar material, which indicated the continuity between the interstitium and the cystic space ${ }^{6,7)}$. The former is the true lumen, and the latter the pseudocyst. The presence of both pseudolumen and true lumen is considered to be a characteristic ultrastructural finding for adenoid cystic carcinoma $^{6,7)}$. In addition, irregular intercellular spaces were frequently found in the myoepithelial islands, as described previously ${ }^{6,7)}$. All of these electron microscopic features were seen in the present case.

\section{要旨}

肺の腺様囊胞癌は主に太いレベルの気管支に発生 し，末梢肺組織に発生することはきわめてまれであ る. 最近, われわれは末梢肺組織に発生した腺様囊胞 癌の 1 例を経験したので, その臨床病理所見について 報告する。症例は 67 歳, 男性で約 1 力月半の咳嗽を 主訴に近くの病院を訪れた。X線検査の結果, 左肺野 に異常陰影を指摘され, 精査, 治療のため当病院に紹 介された。腫瘤は左肺舌区に存在し, 肺癌を疑い, 切 除を行った。切除された肺腫瘤は約 $2.3 \times 3.0 \times 2.6$ 
$\mathrm{cm}$ 大，割面は淡黄白色で，境界は明瞭であった。肉 眼的に腫瘤と大きな気管支との間に明確な関連はみら れなかった。組織学的に, 腫瘤は腺様囊胞癌であっ た。他の部位に原発巣は発見されなかった。組織像に ても腫瘤と太い気管支との間に関係を認めなかった が, 腫瘤の辺縁部に軟骨を欠く細気管支が存在してい ることから，抢そらく 5 ないし 6 次分枝の細気管支よ り発生したものと推定された。

\section{References}

1) Addison, A., Parker, R.T. : Adenoid cystic carcinoma of Bartholin's gland; A review of the literature and report of a patient, Gynecol, Oncol., 5:196 201, 1977.

2) Dalton, M.L., Gatling, R.R. : Peripheral adenoid cystic carcinoma of the lung, South Med. J., $83: 577 \sim$ 579, 1990.

3) Gallagher, C.G., Stark, R., Teskey, J., Kryger, M. : Atypical manifestations of pulmonary adenoid cystic carcinoma, Brit. J. Dis. Chest., 80 : 396 399, 1986.

4) Hajdu, S.I., Huvos, A.G., Goodner, J.Y., Foote, F.W., Beattie, E.J. : Carcinoma of the trachea. Clinicopathologic study of 41 cases, Cancer, $25: 1448 \sim 1456,1970$.

5) Herbst, E.W., Utz, W. : Multifocal dermal-type basal cell adenomas of parotid glands with co-existing dermal cylindromas, Virchows Arch. Pathol. Anat., 403 : 95 102, 1984.

6) Hoshino, M., Yamamoto, I. : Ultrastructure of adenoid cystic carcinoma, Cancer, $25: 186 \sim 198,1970$.

7) Lawrence, J.B., Mazur, M.T. : Adenoid cystic carcinoma : A comparative pathologic study of tumors in salivary gland, breast, lung, and cervix, Hum.
Pathol., $13:$ 916 924, 1982.

8) Mitani, S. : Studies on distribution and histological observation of mucus gland in the bronchial tree of adult human lungs. Lung Cancer., $14: 21 \sim 29,1974$. (in Japanese with English abstract)

9) Olofsson, J., Van Nostrand, A.W.P. : Adenoid cystic carcinoma of the larynx : a report of four cases and a review of the literature, Cancer, $40: 1307 \sim 1313$, 1977.

10) Okura, T., Shiode, M., Tanaka, R., Furukara, A., Kukita, H. : A case of peripheral adenoid cystic carcinoma, Jpn. J. Thrac. Dis., $30: 773 \sim 776$, 1990. (in Japanese with English abstract)

11) Payne, W.S., Ellis, F.H., Woolner, L.B., Moersch, H. J., Minn, R. : The surgical treatment of cylindroma (adenoid cystic carcinoma) and muco-epidermoid tumors of the bronchus, Thorc. Cardiovasc. Surg., $38: 709 \sim 726,1959$.

12) Prempree, T., Villasanta, U., Tang, CK. : Management of adenoid cystic carcinoma of the uterine cervix (cylindroma) : report of six cases and reappraisal of all cases reported in the medical literature, Cancer, 46: 1631 1635, 1980.

13) Spencer, H. : The anatomy of the lung. In "Pathology of the lung", Spencer H, ed. pp 17 77, 1985. Pergamon Press, Oxford.

14) Sweeny, W.B., Thomas, J.M. : Adenoid cystic carcinoma of the lung, Contemp. Surg., $28: 97 \sim 100$, 1986.

15) Thackray, A.C., Lucas, R.B. : Tumors of the major salivary glands. In : Atlas of tumor pathology. Second series, fascicle 10. pp 91 90, Armed Forces Institute of Pathology, Washington D.C., 1974. 